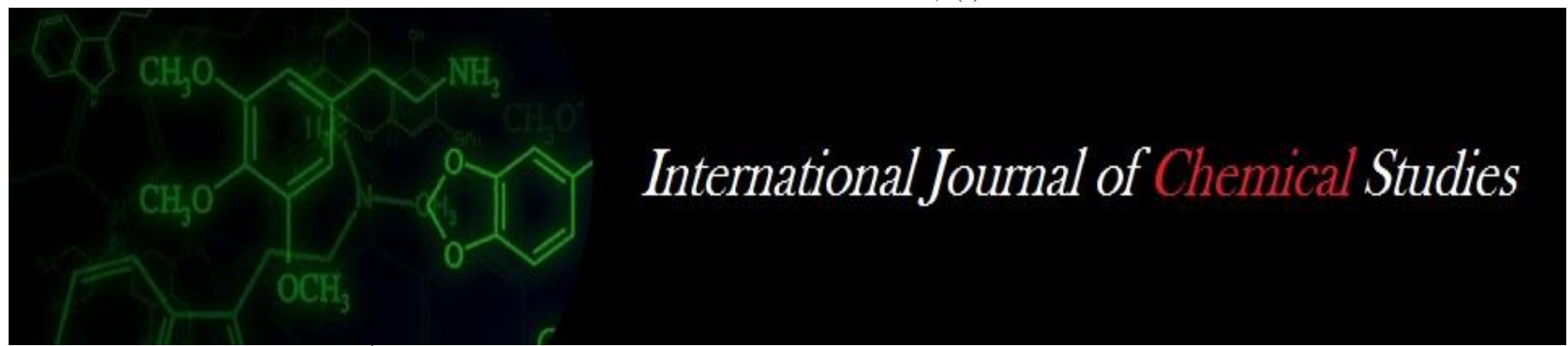

P-ISSN: 2349-8528

E-ISSN: 2321-4902

IJCS 2020; 8(2): 31-34

(C) 2020 IJCS

Received: 11-01-2020

Accepted: 15-02-2020

BN Muthal

Shri Shivaji College, Kandhar,

Nanded, Maharashtra, India
Corresponding Author: BN Muthal

Shri Shivaji College, Kandhar, Nanded, Maharashtra, India

\section{Study of formation constant of schiff base containing Thiazole ring in mixed solvent media and their thermodynamic parameters}

\section{BN Muthal}

DOI: https://doi.org/10.22271/chemi.2020.v8.i2a.8748

\begin{abstract}
The Schiff bases derived from substituted aminothiazole i.e.2-4-Diamino-5-phenylthiazole and RSubstituted salicyladehyde (R-5- $\mathrm{CH}_{3}$, and 5-Cl) or 2hydroxy-1-naphthaldehyde i.e. (5MS) $)_{2} \mathrm{DPT},(5 \mathrm{CS})_{2}$ DPT and (HN) 2 DPT and Rare earth metal ion $\mathrm{La}^{\mathrm{III}}, \mathrm{Ce}^{\mathrm{III}}, \mathrm{Pr}^{\mathrm{III}}, \mathrm{Nd}^{\mathrm{III}}, \mathrm{Sm}^{\mathrm{III}}, \mathrm{Gd}^{\mathrm{III}}, \mathrm{Tb}^{\mathrm{III}}, \mathrm{Ho}^{\mathrm{III}}, \mathrm{Dy}{ }^{\mathrm{III}}$ and $\mathrm{Yb}^{\mathrm{III}}$ Nitrate Salts.

The stability constants of lanthanide metal ion complexes in mixed solvent media in ethanol-water 50:50 $(\mathrm{v} / \mathrm{v})$ at different ionic strength $\mu=0.05,0.1,0.15$ and $0.2 \mathrm{M}\left(\mathrm{NaClO}_{4}\right)$ and at different temperature (35 ${ }^{\circ} \mathrm{C}$ and $45^{\circ} \mathrm{C}$ ) using Bjerrum $\mathrm{pH}$ metric technic as adopted by Irrving-Rossoti.

The formation constants are determined by Half Integral method. The stability constants of Rare earth metal (III) ion complexes have been proportional to their ionic strength. The thermodynamic parameter $(\Delta \mathrm{H}, \Delta \mathrm{G}$ and $\Delta \mathrm{S})$ were determined. The negative free energy change $(\Delta \mathrm{G})$ in each cases indicates that the complexation is spontaneous. The enthalpy changes are exothermic. The positive values of $\Delta \mathrm{S}$ Indicates the reactions are entropically favoured.
\end{abstract}

Keywords: Stability constant, thermodynamic parameter, rare earth metal

\section{Introduction}

In continuation of our earlies work ${ }^{[1-3]}$ deals with the stability constants of Schiff bases and their transition metal $\left(\mathrm{CO}^{\mathrm{ii}} \mathrm{Ni}^{\mathrm{ii}}, \mathrm{Cu}^{\mathrm{ii}}\right.$ and $\mathrm{Zn}^{\mathrm{ii}}$ complexes. The Schiff base derived from substituted amino thiazole i.e. 2aminothiazole. 2-4-diaminothazole and 2-4-diamino-5chloro thiazole and $\mathrm{O}$-hydroxy aldehyde i.e. $\left(5-\mathrm{CH}_{3}\right.$ 5-CI and 2-hydroxy-1-nathaldehydes). The review reveals that no work on 2-4 Diamino-5- phenyl thiazole, the stability constants of Schiff base and their rare earth metal complexes, hence on interest is taken to study the Schiff base and rare earth. Metal complexes in the present investigation. An attempt has been made to study the stability constant, effect of ionic strength and thermodynamic parameter of the Rare earth metal complexes. The Schiff bases derived from 2-4 diamino5- phenylthiazole and Ohydroxy aldehyde i.e. (5- $\mathrm{CH}_{3}$ 5Cland 2-hydroxy-1-naphthaldehyde) and rare earths. $\mathrm{La}^{\mathrm{III}} \mathrm{Ce}^{\mathrm{III}}$, $\mathrm{Pr}^{\mathrm{III}}, \mathrm{Nd}^{\mathrm{III}}, \mathrm{Sm}^{\mathrm{III}}, \mathrm{Gd}^{\mathrm{III}}, \mathrm{Tb}^{\mathrm{III}}, \mathrm{Ho}^{\mathrm{III}}, \mathrm{Dy}^{\mathrm{III}}, \mathrm{Yb}^{\mathrm{III}}$.

\section{Result and Discussion}

Proton-ligand stability constant (PK) values of the ligands (5MS), DPT, (5CS) 2 DPT and $(\mathrm{HN})_{2}$ DPT, were calculated using half-integral method. The values are summarized in table 1. The ligand posses two $\mathrm{pK}$ value due to dissociable proton of the two phenolic -OH group. The protonation of imino nitrogen $(\mathrm{HC}=\mathrm{N})$ does not take place in the $\mathrm{pH}$ range under study. The $\mathrm{pK}$ values of ligands follows the trend: ligand $(5 \mathrm{MS})_{2} \mathrm{DPT}>(5 \mathrm{CS})_{2} \mathrm{DPT}>(\mathrm{HN})_{2} \mathrm{DPT}$ and it is explained on the grounds of basic nature of azomethine nitrogen and phenolic oxygen ${ }^{[4-6]}$.

The ligand (5CS) $)_{2}$ DPT exhibit higher proton-ligand stability constant values than the ligand (HN),DPT and this may be due to presence of $-\mathrm{Cl}$ group in the aromatic ring. $\mathrm{Cl}$ behave as electron releasing group due to mesomeric effect $(+M)$ rather than $(-1)$ effect (inductive effect). Hence electron density on phenyl ring increases and azomethine nitrogen and phenolic oxygen become more basic.

The ligands (5MS) $)_{2}$ DPT posses methyl group at meta position with respective to azomethine group. Due to $(+1)$ effect of methyl group, electron density over phenyl ring increases and 
azomethine nitrogen and phenolic oxygen become more basic. Hence the ligand posses higher stability constant values. Thus $(+\mathrm{I})$ effect of methyl and stronger $(+\mathrm{M})$ of halogen group present in the phenyl ring in the series of the Schiff base support the trend proposed for proton-ligand stability values.

\section{Metal - Ligand stability constants}

The titration curves of acid, ligands and the metal ions are studied. The metal ion curve shows departure from ligand curves at $\mathrm{pH}$ much lower than the $\mathrm{pH}$ of hydrolysis of metal ion and therefore the liberation of proton is due to chelation 68. The metal ligand stability constants were determined by using Half Integral Method and values are summarized in table 2 .

The order of stability constant for the trivalent Rare earth complexes have no regular trends that is in many cases no order is apparent ${ }^{[9-13]}$.

Few observations were made for Rare earth complexes, were the increasing stability constants with increasing atomic number up to $\mathrm{Tb}^{\mathrm{III}}$ and $\mathrm{Yb}^{\mathrm{III}}$ respectively ${ }^{[14-15]}$.

In present observation complexes of Rare earth trivalent metal (III) ions and Schiff bases I, II and III shows increasing in stability from $\mathrm{La}^{\mathrm{III}}$ to $\mathrm{Yb}$ (III) in agreement with increasing Lewis acidity of the metal ions. The order of stability constant of Rare earth complexes with Schiff bases I, II and III has been found to be as follows.

$\mathrm{La}^{\mathrm{III}}<\mathrm{Pr}^{\mathrm{III}}<\mathrm{Nd}^{\mathrm{III}}<\mathrm{Gd}^{\mathrm{III}}<\mathrm{Ce}^{\mathrm{III}}>\mathrm{Sm}^{\mathrm{III}}<\mathrm{Tb}^{\mathrm{III}}<\mathrm{Dy}^{\mathrm{III}}<\mathrm{Ho}^{\mathrm{III}}$
$<\mathrm{Yb}^{\mathrm{III}}$ The Gd" has low value of stability constant then $\mathrm{Sm}^{\mathrm{III}}$ indicates the Gadoliniam break. The $\mathrm{Ce}^{\mathrm{III}}$ cerium show higher value due to the partial conversion of $\mathrm{Ce}^{\mathrm{III}}$ to $\mathrm{Ce}^{\mathrm{IV}}$.

The value of stability constants are decreased with increasing ionic strength which is an agreement with dehye-Hukel equation.

To study the effect of temperature on complexation observed that the value of proton-ligand and metal-ligand decreases with increasing temperature suggesting that low temperature is favorable for complexation. These results are good agreement with pitzer and Garge ${ }^{[15-16]}$.

\section{Thermodynamic parameters}

$(\Delta \mathrm{H}, \Delta \mathrm{G}$ and $\Delta \mathrm{S})$ have been calculated and are summarized in Table 2. The $\Delta \mathrm{G}$ and $\Delta \mathrm{H}$ values are negative, the $\Delta \mathrm{G}$ free energy change in each case indicates that the complexation is spontaneous. The enthalpy changes are exothermic. The $\Delta \mathrm{S}$ values are positive. The positive values of $\Delta \mathrm{S}$ indicates that entropy effect is found to be predominant over enthalpy effect.

\section{Materials and Methods}

All chemicals are A.R. grade. The Schiff bases were prepared by condensation of 2-4 diamino-5- phenylthiazole and 5methylsalicylaldehyde, 5-Chloro salicylaldehyde and 2hydroxy-1-naphthaldehyde i.e. (5MS) $)_{2}$ DPT, $(5 \mathrm{CS})_{2}$ DPT and $(\mathrm{HN})_{2}$ DPT respectively. The structure I, II and III.

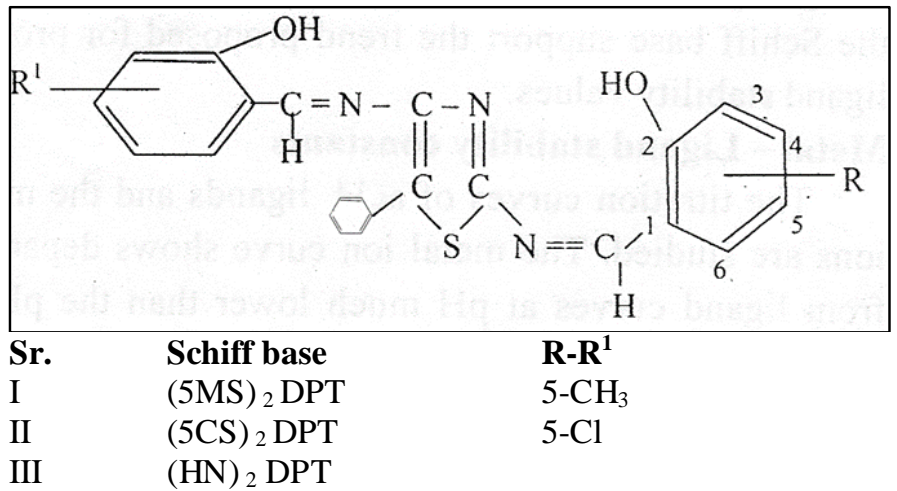

I. (5MS), DPT: [N-bis (5-methylsalicylindine) 2-4 diamino-5-phenyl thiazole]

II. (5CS), DPT: [N-bis (5-Cholorosalicylindine) 2-4, diamino-5- phenyl thiazole]

III. (HN), DPT: [N-bis (2-hydroxy-1-naphthalidine) 2-4 diamino-5-phenyl thiazole]

The fresh solutions of $(5 \mathrm{MS})_{2} \mathrm{DPT},(5 \mathrm{CS})_{2}$ DPT \& $(\mathrm{HN})_{2}$ DPT were prepared in double distilled ethanol and always used. Stock solution of rare earth (Nitrate) salts were prepared in double distilled air-free water and their strength were formed in ethanol - water $(50: 50 \%)(\mathrm{v} / \mathrm{v})$ at different ionic strength $\left(\mathrm{n}^{-}\right)=0.05,0.1,0.015$ and $0.2 \mathrm{M}\left(\mathrm{NaClO}_{4}\right)$ and also at different temperature $\left(35\right.$ and $\left.45^{\circ} \mathrm{C}\right)$ using Bjerrum $\mathrm{pH}$-metric technic as adopted by Irrving and Rossotti. The $\mathrm{pH}$-metric titrations were performed against standard alkali $(\mathrm{NaOH})$ solution as under.

1. Acid titration: A Mixture $\left[2 \mathrm{ml} 0.2 \mathrm{M} \mathrm{HClO}_{4}+1 \mathrm{ml} 0.1 \mathrm{M}\right.$ $\mathrm{NaClO}_{4}+17 \mathrm{ml}$ distilled water $+20 \mathrm{ml}$ ethanol]

2. Schiff base titration: A mixture $\left[2 \mathrm{ml} 0.2 \mathrm{MHClO}_{4}+1 \mathrm{ml}\right.$ $0.1 \mathrm{MNaClO}_{4}+10 \mathrm{ml}$ ligand solution $+17 \mathrm{ml}$ distilled water $+10 \mathrm{ml}$ ethanol]

3. Metal-Ligand titratión: A mixture [2ml $0.2 \mathrm{MHClO}_{4}+$ $1 \mathrm{ml} 0.1 \mathrm{M} \mathrm{NaClO}_{4}+10 \mathrm{ml}$ ligand solution $+2 \mathrm{ml}$ metal ion solution $+15 \mathrm{ml}$ distilled water $+10 \mathrm{ml}$ ethanol]
The titrations were carried out in inert nitrogen atmosphere using Elico-4T-120pH meter with combined glass electrode. The $\mathrm{pH}$ meter was calibrated with standard buffer and the readings were corrected as per literature ${ }^{[17]}$.

From titration curves at different $\mathrm{pH}$ values different sets of $\mathrm{n}$ values were determined of the corresponding free ligands (L) were calculated. The formation curves were drawn and found to be normal. The values of stepwise stability constant $\operatorname{logk}_{1}$, and $\log \mathrm{k}_{2}$, of these complexes were determined at $\mathrm{n}^{-}=0.5$ and $\mathrm{n}^{-}=1.5$ from the formation curves. At each temperature average values of over all stability constant (logk) were plotted against ionic strength for metal ligand system and the values of thermodynamic stability constant $\left(\operatorname{logk}_{1-2}\right)$ at zero ionic strength were calculated by extrapolation.

The thermodynamic stability constants, the values of $\left(\Delta \mathrm{G}^{\circ}\right)$ were calculated at 35 and $45^{\circ} \mathrm{C}$ using relation free energy change

$\Delta \mathrm{Go}=2.303 \mathrm{RT} \log \mathrm{k}^{\mathrm{o}}$ 
Ethalpy $\left(\mathrm{H}^{0}\right)\left[1 / \mathrm{T}_{2}-1 / \mathrm{T}_{1}\right]=-2.303\left(\operatorname{logk} \mathrm{k}^{\mathrm{o}} \mathrm{T}-\left(\log \mathrm{k}^{\mathrm{o}}\right) \mathrm{T}_{1}\right]$ and Entropy $(\Delta \mathrm{S})=\Delta \mathrm{H}^{\circ}-\mathrm{G}^{\mathrm{o}} / \mathrm{T}$

\section{Acknowledgement}

Author are thank to the authorities of Shri Shivaji Education
Society's Kandhar and Principal, Shri Shivaji College, Kandhar for providing facilities. Authors thank to Dr. P.G. More for helpful suggestions and constant encouragement.

Table 1: Stability constant of Rare earth trivalent metal ion in mixed solvent media ethanol - water (50:50) (NaClO) at different ionic strength $25{ }^{\circ} \mathrm{C}^{ \pm} 1$.

\begin{tabular}{|c|c|c|c|c|}
\hline \multirow{2}{*}{ Sr. No. } & \multicolumn{4}{|c|}{ Proton-Ligand and metal-ligand stability constant, Ionic strength $(\mu)-\left(\mathrm{NaClO}_{4}\right) \mathrm{PK}$ and $\log \mathrm{K}$} \\
\hline & $0.05 \mathrm{M}$ & $0.1 \mathrm{M}$ & 0.15M & $0.2 \mathrm{M}$ \\
\hline \multicolumn{5}{|l|}{ 1)LH, $\mathrm{PK}_{1}, \mathrm{PK}_{2}$} \\
\hline I & $9.80,12.70$ & $8.65,11.40$ & $8.50,11.30$ & $8.40,11.10$ \\
\hline II & $8.50,11.40$ & $8.26,11.03$ & $8.05,10.91$ & $8.85,10.79$ \\
\hline III & $8.10,11.32$ & $8.05,11.00$ & $7.90,10.80$ & $7.80,10.70$ \\
\hline 2)La ${ }^{\mathrm{III}} \mathrm{I}$ & 6.95 & 6.45 & 6.15 & 5.95 \\
\hline II & 7.50 & 7.00 & 6.70 & 6.50 \\
\hline III & 7.94 & 7.44 & 7.14 & 6.94 \\
\hline 3)Ce III I & 7.35 & 6.85 & 6.55 & 6.35 \\
\hline II & 7.75 & 7.25 & 6.95 & 6.65 \\
\hline III & 8.30 & 7.70 & 7.40 & 7.20 \\
\hline 4) $\operatorname{Pr}{ }^{I I I} I$ & 7.20 & 6.70 & 6.40 & 6.20 \\
\hline II & 7.80 & 7.30 & 7.00 & 6.80 \\
\hline III & 8.02 & 7.52 & 7.22 & 7.02 \\
\hline 5) $\mathrm{Nd}^{\mathrm{III}} \mathrm{I}$ & 7.40 & 6.90 & 6.60 & 6.40 \\
\hline II & 8.10 & 7.40 & 7.10 & 6.90 \\
\hline III & 8.25 & 7.75 & 7.45 & 7.35 \\
\hline 6) $\mathrm{Sm}^{\mathrm{III}} \mathrm{I}$ & 7.45 & 6.95 & 6.65 & 6.46 \\
\hline II & 7.82 & 7.32 & 7.02 & 6.82 \\
\hline III & 8.30 & 7.80 & 7.50 & 7.30 \\
\hline 7) $\mathrm{Gd}^{\mathrm{III}} \mathrm{I}$ & 7.30 & 6.80 & 6.50 & 6.30 \\
\hline II & 7.75 & 7.25 & 6.96 & 6.76 \\
\hline III & 8.05 & 7.63 & 7.34 & 7.14 \\
\hline 8) $\mathrm{Tb}^{\mathrm{III}} \mathrm{I}$ & 7.45 & 6.95 & 6.65 & 6.65 \\
\hline II & 7.80 & 7.30 & 7.00 & 6.80 \\
\hline III & 7.36 & 7.85 & 7.66 & 7.47 \\
\hline 9) $\mathrm{Ho}^{\mathrm{III}} \mathrm{I}$ & 7.53 & 7.03 & 6.73 & 6.53 \\
\hline II & 7.92 & 7.42 & 7.22 & 6.98 \\
\hline III & 8.32 & 7.80 & 7.50 & 6.36 \\
\hline 10) Dy ${ }^{I I I} I$ & 7.45 & 6.95 & 6.66 & 6.47 \\
\hline II & 7.96 & 7.46 & 7.75 & 6.85 \\
\hline III & 8.35 & 7.85 & 7.56 & 7.36 \\
\hline 11) $\mathrm{Yb}^{\mathrm{III}} \mathrm{I}$ & 7.67 & 7.17 & 6.85 & 6.66 \\
\hline II & 8.05 & 7.52 & 7.22 & 7.03 \\
\hline III & 8.40 & 7.90 & 7.61 & 7.42 \\
\hline
\end{tabular}

Table 2: Metal Ligand stability constant of Rare earth trivalent metal ion in mixed solvent media ethanol water (50-50) (V/V) at ionic strength $0.1 \mathrm{M} \mathrm{NaClO}_{4}$ and their thermodynamic parameters.

\begin{tabular}{|c|c|c|c|c|c|c|c|c|c|c|c|}
\hline \multirow{2}{*}{ Cation } & \multicolumn{3}{|c|}{$\log ^{k}$} & \multicolumn{3}{|c|}{$-\Delta \mathbf{G ~ K J ~ M o l}{ }^{-1}$} & \multicolumn{3}{|c|}{$\Delta \mathrm{S} \mathrm{JK} \mathrm{Mol}{ }^{-1}$} & \multicolumn{2}{|c|}{$-\Delta \mathrm{H} \mathrm{KJ} \mathrm{Mol}^{-1}$} \\
\hline & $25^{0 \mathrm{C}}$ & $35^{0 \mathrm{C}}$ & $45^{0 \mathrm{C}}$ & I & II & III & I & II & III & I & II \\
\hline $\mathrm{La}^{\mathrm{III}} \mathrm{I}$ & 6.45 & 6.35 & 6.26 & 32.50 & 32.80 & 27.49 & 28.12 & 28.10 & 44.25 & 24.11 & 168.52 \\
\hline II & 7.00 & 6.90 & 6.81 & 33.10 & 34.95 & 33.80 & 41.00 & 43.63 & 09.56 & 21.50 & 36.80 \\
\hline III & 7.44 & 7.34 & 7.25 & 38.00 & 38.31 & 29.25 & 31.76 & 31.76 & 814.01 & 28.51 & 288.15 \\
\hline $\mathrm{Ce}^{\mathrm{III}} \mathrm{I}$ & 6.85 & 6.76 & 6.65 & 33.85 & 34.51 & 33.08 & 63.52 & 63.53 & 41.53 & 14.90 & 46.35 \\
\hline II & 7.25 & 7.15 & 7.06 & 36.80 & 35.99 & 34.61 & 109.00 & 108.70 & 27.21 & 69.52 & 43.26 \\
\hline III & 7.70 & 7.60 & 7.50 & 39.11 & 39.73 & 37.35 & 62.10 & 62.36 & 120.16 & 20.50 & 75.52 \\
\hline $\operatorname{Pr}^{\mathrm{III}} \mathrm{I}$ & 6.70 & 6.60 & 6.51 & 33.50 & 33.85 & 32.13 & 37.17 & 37.17 & 71.10 & 22.38 & 54.78 \\
\hline II & 7.30 & 7.20 & 7.11 & 35.71 & 29.26 & 34.11 & 64.00 & 25.09 & 376.63 & 227.40 & 154.10 \\
\hline III & 7.52 & 7.42 & 7.33 & 38.72 & 38.90 & 33.73 & 37.92 & 38.01 & 401.17 & 27.18 & 161.44 \\
\hline $\mathrm{Nd}^{\mathrm{III}} \mathrm{I}$ & 6.90 & 6.80 & 6.70 & 33.94 & 34.59 & 33.14 & 55.85 & 55.88 & 30.00 & 17.26 & 42.71 \\
\hline II & 7.40 & 7.30 & 7.20 & 37.80 & 37.65 & 34.92 & 141.02 & 14.01 & 164.23 & 42.00 & 87.18 \\
\hline III & 7.75 & 7.85 & 7.56 & 39.29 & 39.88 & 38.00 & 60.74 & 60.76 & 68.82 & 21.15 & 59.94 \\
\hline $\mathrm{Sm}^{\mathrm{III}} \mathrm{I}$ & 6.95 & 6.85 & 6.70 & 32.28 & 34.73 & 33.41 & 24.58 & 20.54 & 27.70 & 41.09 & 42.25 \\
\hline II & 7.32 & 7.22 & 7.20 & 37.52 & 37.13 & 34.75 & 38.30 & 38.50 & 139.13 & 49.02 & 78.92 \\
\hline III & 7.80 & 7.70 & 7.56 & 39.25 & 39.94 & 38.00 & 67.45 & 67.47 & 72.70 & 19.12 & 61.16 \\
\hline $\mathrm{Gd}^{\mathrm{III}} \mathrm{I}$ & 6.80 & 6.70 & 6.60 & 33.77 & 46.00 & 32.51 & 52.95 & 91.03 & 70.45 & 17.92 & 54.96 \\
\hline II & 7.25 & 7.15 & 7.05 & 36.92 & 36.00 & 34.58 & 94.25 & 94.26 & 75.61 & 65.03 & 10.56 \\
\hline III & 7.63 & 7.53 & 7.44 & 38.84 & 39.40 & 36.75 & 52.46 & 52.47 & 145.46 & 23.18 & 83.04 \\
\hline $\mathrm{Tb}^{\mathrm{III}} \mathrm{I}$ & 6.95 & 6.86 & 6.76 & 32.75 & 34.65 & 33.45 & 27.35 & 32.70 & 18.67 & 24.55 & 39.36 \\
\hline
\end{tabular}




\begin{tabular}{|c|c|c|c|c|c|c|c|c|c|c|c|}
\hline II & 7.30 & 7.20 & 7.10 & 37.53 & 37.24 & 34.65 & 27.10 & 27.17 & 150.50 & 45.64 & 82.53 \\
\hline III & 7.85 & 7.75 & 7.66 & 39.43 & 40.45 & 39.01 & 102.85 & 102.80 & 21.10 & 8.75 & 45.75 \\
\hline $\mathrm{Ho}^{\mathrm{III}} \mathrm{I}$ & 7.03 & 6.97 & 6.87 & 34.43 & 34.90 & 33.60 & 45.23 & 45.26 & 22.28 & 20.90 & 40.71 \\
\hline II & 7.42 & 7.32 & 7.22 & 38.03 & 34.16 & 29.26 & 11.95 & 11.94 & 799.00 & 34.45 & 283.38 \\
\hline III & 7.80 & 7.70 & 7.60 & 39.40 & 40.12 & 38.30 & 72.01 & 72.00 & 66.85 & 17.90 & 59.58 \\
\hline Dy ${ }^{\text {III I }}$ & 6.95 & 6.85 & 6.76 & 32.27 & 34.68 & 33.46 & 23.52 & 11.88 & 16.60 & 39.32 & 39.77 \\
\hline II & 7.46 & 7.36 & 7.27 & 38.22 & 38.30 & 29.25 & 08.70 & 08.70 & 124.41 & 35.60 & 68.86 \\
\hline III & 7.85 & 7.70 & 7.61 & 39.50 & 41.57 & 39.18 & 132.71 & 103.91 & 10.71 & 9.37 & 42.62 \\
\hline $\mathrm{Yb}^{\mathrm{III}} \mathrm{I}$ & 7.17 & 7.07 & 6.98 & 36.43 & 32.80 & 34.15 & 36.29 & 36.33 & 34.70 & 145.00 & 45.28 \\
\hline II & 7.52 & 7.42 & 7.33 & 38.98 & 39.85 & 32.05 & 36.10 & 36.11 & 557.60 & 27.70 & 215.75 \\
\hline III & 7.90 & 7.71 & 7.71 & 34.00 & 40.52 & 39.33 & 42.40 & 38.90 & 4.72 & 160.67 & 37.80 \\
\hline
\end{tabular}

\section{References}

1. More PG, Muthal BN, Indian Chem. Soc. 2006; 83:3638.

2. More PG, Muthal BN, Proceeding of Int. Congress of Chemistry and Environment, 2005, 655-657.

3. Muthal BN, Kandhare NT, Research Journal of SRTM. University, Nanded, 2007, 24-28.

4. Gurkan P, Gunduz NJ, Ind Chem. Soc. 1997; 74:713.

5. Naikwade DS, Mane PS, Chondhelkar TK, J Ind. Chem., Soc. 2001; 78:41.

6. Sanyal P, Sar P, Sangupta GP. Ind. Chem. Soc. 2002; 79:614.

7. Pauling L. The Nature of Chemical Bond Oxfordand IBH, Culcuta, 1963.

8. Harkins TR, Freiser HJ, Am. Chem. Soc.1956; 78:1143.

9. Krishnamurthy N, Prasad NSK, Indian J. Chem. 1966; $4: 316$.

10. Serdyak LS, Smirnova VV, Zh anal. khim: 1965; 20:161.

11. Komok VN, Serebrennikov VV, Zh. neorg khim. 1966; 21:90.

12. Serdyuk LS, Smirnov VS, Zh. neorg khim. 1964 19:451.

13. Panasyuk VD, Golub VA, Zh. neorg khim. 1965; 20:2732.

14. Chondhekar TK, Dhuley DG, Ind. J Chem. 1989; 20A:1014-1015.

15. Garg BS, Singh BK, Deo Nandan Kumar, Singh PK, Ind. J Chem. 2003; 42A:79.83.

16. Pitzer KS, J Am. Chem. Soc. 1937; 50:2365.

17. G Douheret, Bull. Soc, Chim, Fr. 1967; 1412:3122. 